\title{
Design of Solar Water Heater Using Collector Cylindric Parabolic and Coil Heater as Absorber at Focus Point
}

\author{
Sari Farah Dina ${ }^{*}$, Jufrizal $^{2}$, Siti Masriani Rambe ${ }^{1}$, Harry P. Limbong ${ }^{1}$, Edwin H. Sipahutar ${ }^{1}$ \\ ${ }^{1}$ Center for Research and Standardization of Industry Medan, Indonesia, J1. Sisingamangaraja No. 24 Medan 20217, Indonesia \\ ${ }^{2}$ Faculty of Mechanical Engineering, Medan Institute of Technology, Medan, Indonesia
}

\begin{abstract}
Solar thermal water heating systems have been developed to replace conventional heating. Therefore, the design of a parabolic cylinder collector-type solar heating unit with a coil-shaped heater (absorber) has been carried out. The cylindrical collector is made of an aluminum plate covered with a reflective sticker and the base is insulated, having a diameter, height, length, and position of the focal point $150,60,200$, and $22.4 \mathrm{~cm}$, respectively. The coil water heater of 3/8-inch diameter copper pipe having a diameter, pitch, and length of 20,3 , and $200 \mathrm{~cm}$, respectively. The concentration ratio between collector area and heating pipe area (absorber) is 3.6. The results of heating trials conducted from 10:00 to 16:00 WIT, in Duplo to 100 liters of water circulated through the heating pipe at a speed of $0.017 \mathrm{~kg} / \mathrm{sec}$, indicate that heating is affected by fluctuations in radiation intensity. Thermal efficiency is inversely proportional to heating time. the lower the time when the difference between the temperature of the incoming and outgoing water gets smaller, or in other words in the evening the water temperature approaches a steady state. The achieved maximum water-heating temperature is $53 \mathrm{C}$ in the average radiation range during the test is 687 $693 \mathrm{~W} / \mathrm{m}^{2}$.
\end{abstract}

Keywords: Solar Heater, Water, Parabolic Collector, Heating Coil, Efficiency

\section{Introduction}

The tsunami disaster can cause negative impact, both the use of solar energy in artificial form has been very widely used, especially in the fields of electricity generation, photolysis, drying, refrigeration, desalination, cooking, heating water for industrial distillation purposes. [1]. In daily life, heating water for sanitation purposes, especially for bathing, has become a demand, especially in urban communities. Currently, to meet these needs, commercial water heating systems that are found still use electricity and gas. Types of solar-based heating have also continued to be developed and this technology is considered efficient compared to heaters that use fossil energy [2].

Of all the types of solar thermal generator available, the vacuum tube and flat plate solar collector types have been shown to have high thermal efficiency [3]. The flat plate type collector showed that thermal efficiency increases with the increase in the number of abrasive pipes in the collector and the pipes arranged in a zigzag manner provide the efficiency increases [4].

The performance of water heating systems using solar photovoltaic connected directly to DC currents have been studied and compared with solar photovoltaic systems. The results showed that the photothermal system provides 3 times higher efficiency than photovoltaic systems [5]. The higher the value of the solar collector thermal conductivity, the better to absorb heat due to solar radiation that hits it [6]. Analysis of the performance of a flat plate collector type solar water heater with an absorber in the form of a spiral flat pipe showed that the maximum average temperature of the water storage tank is $60^{\circ} \mathrm{C}$ obtained at a water flow rate of $0.1 \mathrm{~kg} / \mathrm{s}$ [7]. Another analytical study was carried out comparing the performance of flat plate collector type solar water heater with unmodified and modified copper pipe arrangement for heating water [8].

The cylindrical collector type solar water heater made of high-quality glass and a spiral ring water pipe made of copper as an absorber has been tested and the results show that thermal efficiency is $41.8 \%$ [9]. The design and trial of a parabolic collector type solar cooker have been carried out under conditions of average radiation intensity of $520 \mathrm{Watt} / \mathrm{m}^{2}$. The results show that the perfect cooking time is 90 minutes with a thermal efficiency of up to $56 \%$ [10]. The paddy drying using a parabolic cylinder type solar collector has also proven capable of drying rice from $28 \%$ to $14 \%$ moisture content in 40 - 50 minutes for every $5 \mathrm{~kg}$ of rice $/$ batch. During the trial, the average radiation intensity was 471 Watt $/ \mathrm{m}^{2}$ and the average temperature in the drying cylinder was $67^{\circ} \mathrm{C}[11]$.

On the basis of the research that has been carried out, the idea emerged to design a simple water heater unit for sanitation needs for Indonesian families. This solar water heating system is designed to increase the 
temperature to more than $40^{\circ} \mathrm{C}$ with a capacity of 100 liters.

Parabolic Cylinder Collector Type Water Heater

Solar thermal technology with a concentric collector type (cylindrical or parabolic) as a heat generator has been developed for various purposes such as cooking, refrigeration systems, and drying [10, 12, 13]. In a parabolic or cylindrical (curved) type collector, sunlight is collected using a reflective surface and then forwarded/directed to a single focal point (f). This type of heat collector technology is capable of producing temperatures reaching temperatures in the range 60 $250^{\circ} \mathrm{C}[14]$.

There are several parameter terms that are used as the basis for calculations during the design process. If we have set the diameter of the stretch (D) and the height of the curve (h) at a certain value, then based on the parabola equation (equation 1) it can be known the height of the focal point (f). Determination of the focal point is important because all incoming rays hitting the surface of the parabolic reflector will be reflected precisely on the focal point. It is at this focal point that the object that functions as an absorber is placed to get maximum heating. Here are common parabolic equations [15]:

$$
X^{2}=4 . f . Y
$$

where $X=\frac{D}{2}$, and $\mathrm{D}$ is diameter of parabolic

Through this equation, the dimensions of the parabola can be determined from the coordinates of each of the $\mathrm{X}$ and $\mathrm{Y}$ axes and the position of the desired focal point.

\section{Materials and Methods}

\subsection{Materials}

Solar water heater consists of: parabolic cylinder collector, coil pipe as a heater/absorber, and utilities.

The collector is made of type A1 6061 aluminum plate as the base and covered by an aluminum sticker on the outer surface. The heating coil is made of copper pipe ( $3 / 8$ inch in diameter).

The utilities consists of: a water tank made of polyethylene with a capacity of $110 \mathrm{~L}$ ) covered with rockwool (thickness of $40 \mathrm{~mm}$ ); water pump to circulate water (rate of $700 \mathrm{~L} / \mathrm{hr}$ ), valve of $3 / 4$ inch type ball and mild steel pipe ( 1 inch of diameter) as frame and support.

\subsection{Methods}

\subsubsection{The design of a parabolic cylinder collector type water heater}

a. Determination of parabolic equations as a basis for collector design

The solar collector used is made of an aluminum plate $(0.75 \mathrm{~mm}$ thick $)$ and coated with a reflective mirror sticker. The diameter (D) and height (h) and length (t) of the parabolic cylinder collector in $\mathrm{cm}$ are 150,60, and 200, respectively. From equations 1, the parabolic collector equation is obtained as follows:

$$
\mathrm{Y}=0.01068 . \mathrm{X}^{2}
$$

Based on equation 2), then the parabolic cylindrical collector structure is built.

\section{b. Water heating coil design (absorber)}

The coil specifications is made of copper pipe material with inside diameter of $3 / 8$ inch. The heating coil to be made need the required certain linear length which is calculated by the following equation [16]:

$$
\begin{aligned}
& \mathrm{L}=\mathrm{N} \cdot \sqrt{\left(\pi \cdot \mathrm{D}_{\text {coil }}\right)^{2}+p^{2}} \\
& N=\frac{H}{p}
\end{aligned}
$$

where $\mathrm{N}$ is the number of coils turns

Table 1. Water Heater Coil Specifications (Absorber)

\begin{tabular}{|l|l|c|r|}
\hline No & Parameter & Unit & Value \\
\hline 1 & Coil Pipe Diameter & $\mathrm{cm}$ & 0.9525 \\
\hline 2 & Coil Diameter $(\mathrm{D})$ & $\mathrm{cm}$ & 20 \\
\hline 3 & Coil Length $(\mathrm{H})$ & $\mathrm{cm}$ & 200 \\
\hline 4 & Pitch $(\mathrm{p})$ & $\mathrm{cm}$ & 3 \\
\hline
\end{tabular}

\subsubsection{Performance of Solar Water Heater}

\section{a. Concentration Rasio of Collector}

The concentration ratio is an important parameter to describe the amount of solar energy that can be concentrated by a parabolic cylinder collector. The geometric concentration ratio is defined as the ratio between the area of the collector opening and the surface area of the coil pipe (absorber), calculated using the following equation [17]:

$$
C R_{g}=\frac{A_{a}}{A_{r}}
$$

where:

$\mathrm{CR}_{\mathrm{g}}$ : Geometric Concentration Ratio

$\mathrm{A}_{\mathrm{a}} \quad$ : Collector Opening Area, $\mathrm{m}^{2}$

$\mathrm{A}_{\mathrm{r}} \quad$ : coil pipe cross-sectional area (absorber), $\mathrm{m}^{2}$

The opening area of the parabolic cylinder collector is calculated as $1 / 2$ the surface area of the cylinder tube, which is according to the following equation:

$$
A_{a}=\pi . r . L
$$

where:

r : Parabolic Cylinder Radius $(1 / 2 \mathrm{D})$

L : Parabolic Cylinder Length

The cross-sectional area of the entire coil pipe is calculated using the following equation:

$\mathrm{A}_{\mathrm{r}}=$ circumference $\mathrm{x}$ pipe length $(\mathrm{L})$

\section{b. Water Heater Performance}

The performance of this water heater is calculated based on the thermal efficiency which is the ratio of the useful energy to the radiation energy received by the solar collector. The amount of thermal energy that can be 
received by the solar collector surface to be reflected into the absorber (coil) is :

$$
Q_{\text {in }}=I . A . \Delta t
$$

The amount of energy needed to heat the water from ambient conditions $\left(\mathrm{T}_{1}\right)$ to reach the desired temperature $\left(T_{2}\right)$ is expressed as used energy and can be calculated by the following equation :

$$
\mathrm{Q}_{\text {used }}=\mathrm{m}_{\text {water }} \mathrm{X} \mathrm{Cp}_{\mathrm{water}} \mathrm{X}\left(\mathrm{T}_{2}-\mathrm{T}_{1}\right)
$$

The thermal efficiency of the collector is calculated as follows :

$$
\eta=\frac{Q_{\text {used }}}{Q_{\text {in }}} \times 100 \%
$$

Where :

$\mathrm{Q}_{\text {used }}$ is the energy required to raise the water temperature from $\mathrm{T}_{1}$ to $\mathrm{T}_{2}, \mathrm{~J}$

$\mathrm{Q}_{\text {in }} \quad$ thermal energy received by the collector, J

I solar radiation, Watt $/ \mathrm{m}^{2}$

A collector area, $\mathrm{m}^{2}$

$\Delta t \quad$ Time

$\mathrm{M}_{\text {water }}$ the mass of water that is heated, $\mathrm{kg} / \mathrm{det}$

$\mathrm{Cp}_{\text {water }} \quad$ water specific heat capacity, $4200 \mathrm{~J} / \mathrm{kg} .{ }^{\circ} \mathrm{C}$

$\mathrm{T}_{2} \& \mathrm{~T}_{1}$ water temperature after and before entering the heater, ${ }^{\circ} \mathrm{C}$

To determine the design of a solar water heating system, it is first necessary to establish the energy balance between the useful energy and the energy supplied (radiant heat energy received by the collector). A good design is if the energy supplied is greater than the useful energy.

\subsubsection{Water Heater Trials Set-up}

The trial was carried out in Medan, North Sumatra during March - April 2021, starting from 10:00 to 16:00 WIT. Data were collected at 30-minute intervals. The measuring instrument used in this study is to measure the intensity of solar radiation and environmental temperature using a solar power meter with units of watts $/ \mathrm{m}^{2}$. The data logger thermometer is connected to a thermocouple, attached to the wall of the water heater coil to record changes in water temperature.

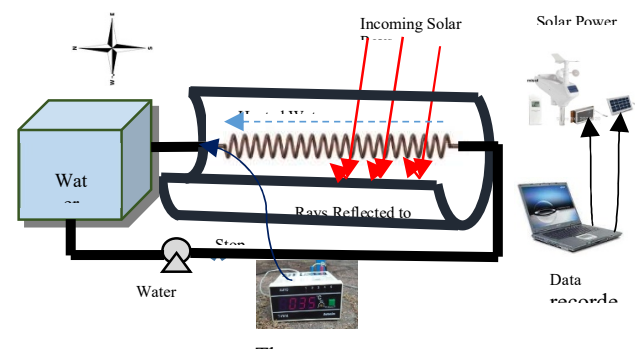

Fig. 1. Solar Water Heater Trial Set-up with Coil Heater and Parabolic Cylindrical type collector

The trial carried out a water flow rate of 1 liter $/$ minute $(0.017 \mathrm{~kg} / \mathrm{s})$. Regulations are made through controlling the valve opening which earlier has been determined through a simple test, namely looking at the relationship of the opening to the 60 seconds ( 1 minute) time needed to hold 1 liter of water. The stopwatch is used to record time.

After the storage tank is filled with 100 liters of water and the collector is positioned in such a way as shown in Figure 1. Then all measuring instruments are installed and the trial starts by running the pump and making sure the stop position of the faucet is at a flow rate of 1 liter/minute. Testing starts at 10:00 and ends at 16:00 WIT and it is ensured that all data is recorded and stored properly.

\section{RESULTS AND DISCUSSION}

\subsection{Design Results}

The diameter (D) and height (h) and length (l) of the parabolic cylinder collector are determined in units of $\mathrm{cm}$ to be 150, 60 and 200 respectively. from equations 1) and 2) the focal point position (f) on the $Y$ axis is $23.44 \mathrm{~cm}$. The heating coil pipe in the solar water heater system functions as an absorber, so that its axis is placed at the focal point (Figure 2). The water heater pipe is designed in such a coil shape so that the water retention time during the heating process (charging) by the solar collector can be longer so that the heat transfer process takes place more effectively. The choice of copper as the coil material is to make it easier to form a coil as well as a good heat conductor.

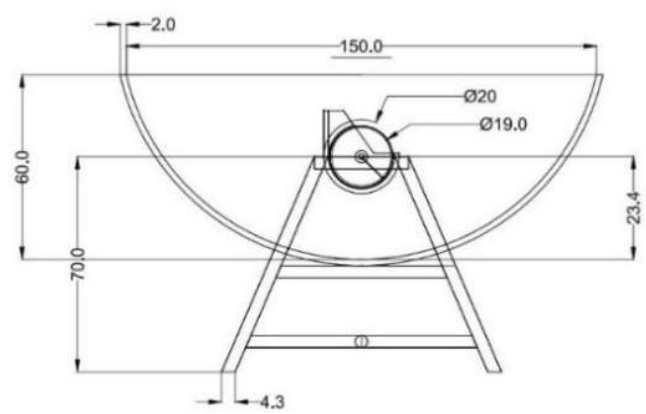

1. Side View

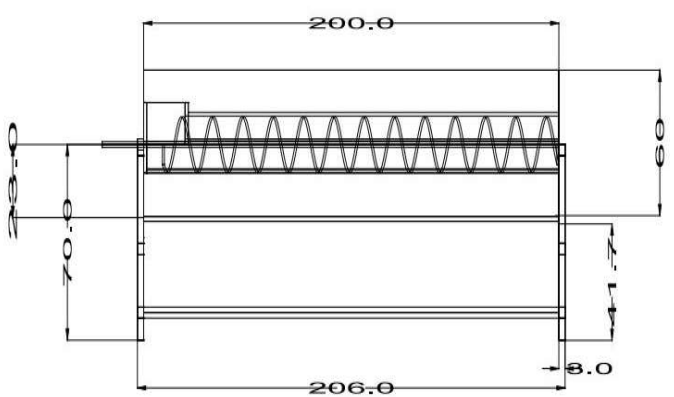

2. Front View

Fig.2. The design results of the parabolic cylinder type solar water heater Heating Coil Design (Absorber) 
Based on the data from Table 1, the linear length of the heating coil pipe is calculated using equations 3 ) and 4 ), the results of the water heater coil pipe design are obtained as shown in figure 3 .

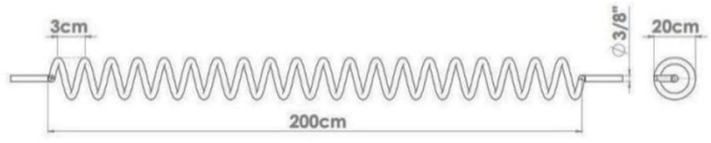

Fig.3. Water Heater Coil Pipe Design (Absorber)

\subsection{Permormance}

\subsubsection{Concentration ratio}

The higher the concentration ratio value, the greater the amount of radiation energy that is concentrated by the parabolic cylinder collector. By using equations 5), 6) and 7) the value of the concentration ratio between the collector and the absorber is obtained as follows:

$$
C R_{g}=3.6
$$

\subsubsection{Test Result}

The results of measuring the temperature of the coil pipe at the entry point $\left(\mathrm{T}_{\text {in }}\right)$ and the pipe exit point $\left(\mathrm{T}_{\text {out }}\right)$, ambient temperature $\left(\mathrm{T}_{\text {Ambient }}\right)$ and the intensity of solar radiation during the heating process are presented at Figures 4 and 5 . The mean radiation intensities for trial -1 and trial-2 were 687 and $693 \mathrm{~W} / \mathrm{m}^{2}$, respectively. The average water temperature reached until the heating process ended (16:00 hours) was lower in trial- $1\left(47^{\circ} \mathrm{C}\right)$ than in trial- $2\left(51^{\circ} \mathrm{C}\right)$. This is because the radiation intensity of trial-1 is lower than trial-2.

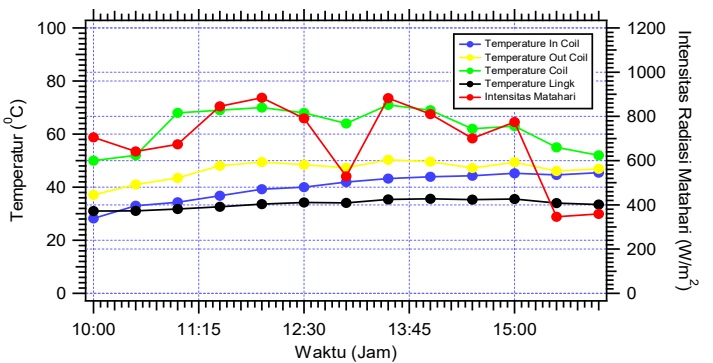

Fig.4. Profile of temperature and solar radiation intensity in trial-1 (March $\left.25^{\text {th }}, 2021\right)$

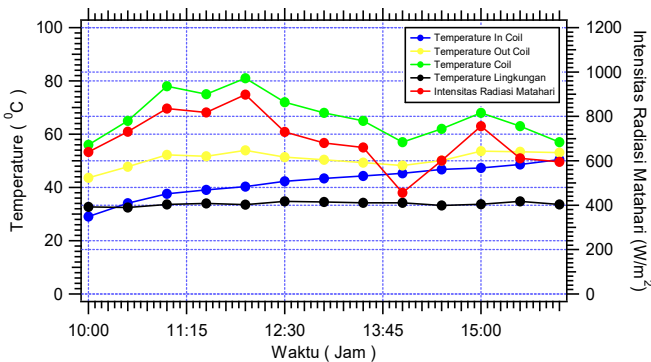

Fig. 5. Profile of temperature and solar radiation intensity in trial-2 (April $6^{\text {th }}, 2021$ )

\subsubsection{Water Heater Performance}

The performance of the water heater in this trial is expressed by thermal efficiency, where how much incoming energy (solar radiation) can be absorbed to increase the temperature of the water (used energy). Used energy, incoming energy and thermal efficiency are calculated using equations 8), 9) and 10), so is obtained the thermal efficiency as long as water is heated.

The efficiency for the overall tests carried out is presented in Figure 6. In general, the thermal efficiency is lower when the difference in temperature of water into the coil $\left(\mathrm{T}_{\text {in }}\right)$ and temperature of water out of the coil $\left(\mathrm{T}_{\text {out }}\right)$ is lower. This shows that the sensible heat required is getting smaller, while the heat supplied by solar radiation is still high. Therefore, the thermal efficiency in the afternoon decreases. From the duplo heating, it can be seen that trial- 2 has a higher thermal efficiency than trial-1. This is because the difference in temperature of the water entering and leaving the heating coil in trial-2 is greater than in trial-1.

The efficiency of a water heater using a glass cylinder tube that functions as a recipient of solar radiation with a heating coil made of copper used by foreign researchers [9] also shows a pattern of decreasing efficiency at the end of the experiment, when the difference between the temperature of the water entering and leaving the heater is getting smaller and this is said to be close to steady conditions.

The low thermal efficiency of the parabolic cylinder collector type water heater that is designed, cannot be separated from the selection of the reflector sticker material that is not yet optimal, it can reflect all the light received by the collector to the focal point where the heating pipe is placed so that there is a lot of heat loss [18].

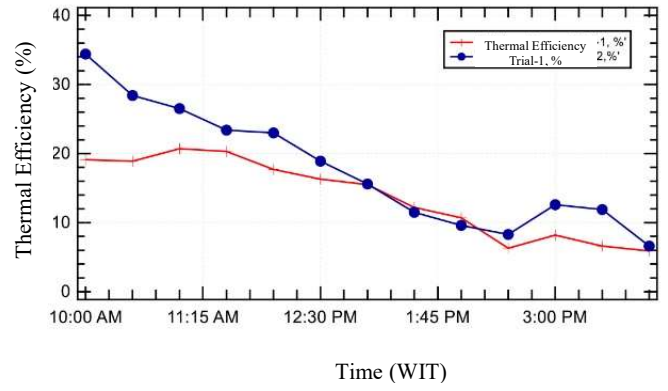

Fig. 6. Thermal Efficiency of Water Heating

\section{CONCLUSION}

A simple solar water heater using a cylindric parabolic type collector has been designed. The collector have a diameter, height, and length of 150,60 , and $200 \mathrm{~cm}$, respectively. From this dimension, the parabolic equation is obtained, namely $\mathrm{Y}=0.01068 . \mathrm{X}^{2}$, and the focal point is $22.4 \mathrm{~cm}$. The heater/absorber is made of a $3 / 8$-inch diameter copper pipe which is formed a coil with a coil diameter, pitch, and length of 20,3 , and 200 
$\mathrm{cm}$, respectively. The concentration ratio between collector area and heating pipe area (absorber) is 3.6. The trial results conducted from 10:00 to 16:00 WIT, in duplo to 100 liters of water circulated at a speed of 0.017 $\mathrm{kg} / \mathrm{sec}$, indicate that heating is affected by fluctuations in radiation intensity. The thermal efficiency of heating is lower when the difference between the temperature of the incoming and outgoing from the coil gets smaller. The maximum water heating temperature that can be achieved is $51{ }^{\circ} \mathrm{C}$.

\section{References}

1. Zekai Sen, Solar Energi Fundamentals and Modeling Techniques, Atmosphere, Environment, Climate Change and Renewable Energy, ISBN 9781-84800-133-6, e-ISBN 978-1-84800-134-3, DOI 10.1007/978-1-84800-134-3, Springer, (2008).

2. Hossain, M.S., Saidur, R., Fayaz, H., Rahim, N.A., Islam, M.R., Ahamed, J.U., and Rahman, M.M., (2011), Review on Solar Water Heater Collector and Thermal Performance of Circulating Pipe, Renewable and Sustainable Energy Reviews, vol. 15: 3801-3812.

3. Liu Z, Li H, Tang X, et al., (2016), Extreme learning machine: A new alternative for measuring heat collection rate and heat loss coefficient of water-in-glass evacuated tube solar water heaters. SpringerPlus 5(626): 1-8.

4. Sathish D., Veeramanikandan M., Thirunavukkarasu R., Tamilselvan R., Karthickmunisamy T., 2017, International Journal of ChemTech Research, Vol.10 No.3, pp 705-713, CODEN (USA): IJCRGG, ISSN: 0974-4290, ISSN(Online):2455-9555.

5. Tomas Matuska and Borivoj Sourek, Performance Analysis of Photovoltaic Water Heating System, (2017), Hindawi , J. Photoenergy Vol. 2017, Article ID 7540250, 10 pages https://doi.org/10.1155/2017/7540250.

6. Esdras Nshimyumuremyi and Wang Junqi, Thermal efficiency and cost analysis of solar water heater made in Rwanda, (2018), Energy Exploration \& Exploitation 0(0), p: 1-15, doi: $10.1177 / 0144598718815240$, journals.sagepub.com/home/eea)

7. Sacithra A., Manivannan A., Performance analysis of solar water heater with flattened tube spiral absorber using forced circulation, (2019), International Journal of Green Energi, ISSN: 15435075 (Print) 1543-5083 (Online) Journal, DOI: 10.1080/15435075.2019.1641102.

8. Balaji K., Idrish Khan A., Ganesh Kumar P., Iniyan S., Ranko Goic, Experimental analysis on free convection effect using two different thermal performance enhancers in absorber tube of a forced circulation flat plate solar water heater, Solar Energy, Vol. $\mathbf{1 8 5}$ p: 445 - 454, (2019),https://doi.org/10.1016/j.solener.2019.04.0

$\underline{89}$.

9. Hussain Al-Madani, The performance of a cylindrical solar water heater, Renewable Energi, Vol. 31 p: 1751-1763, (2006), doi:10.1016/j.renene.2005.09.010.

10. Dina S.F., Ilmi Abdullah, Siti Masriani R., Putra M. Siregar, Design of Parabolic Solar Cooker: As Alternative Cooker Trough Go Green in Medan, Indonesia, Indian Journal of Science and Technology, Vol 12(10) p: 1 - 9, (2019), doi: 10.17485/ijst/2019/v12i10/142206

11. Dina S.F., Jufrizal, Siti Masriani R., Harry P. Limbong, Edwin H. Sipahutar, Kajian Pengeringan Padi Menggunakan Silinder Pengering Yang Dilengkapi Screw Conveyor Dan Kolektor Surya Tipe Silinder Parabola, Jurnal Dinamika Penelitian Industri Vol. 31 No. 2, hal: 170 - 180, (2020), http://dx.doi.org/10.28959/jdpi.v31i2.

12. Yahuza I., Rufai Y.A., Tanimu, Design, Construction and Testing of Parabolic Solar Oven, Journal of Applied Mechanical Engineering, 5:212, (2016), doi:10.4172/2168-9873.1000212

13. Omotoyosi O. C., Robert T. D. and Wikus van Niekerk, 2017, A Novel Indirect Parabolic Solar Cooker, Journal of Electrical Engineering 5 (2017) 137-142, ISSN: 2168-9873, doi: 10.17265/23282223/2017.03.003.

14. Robert Foster, Majid Ghassemi, Alma Cota, Solar Energy - Renewable Energy and the Environment., Energy and Environment Series, Series editor Abbas Ghassemi, ISBN: 978-1-4200-7566-3 (Hardback), CRC Press, (2009),

15. Rai G.D., Solar Energy Utilisation, Khanna Publisher, Nai Sarak Delhi, ISBN 978-81-7409184-0, p: 202 - 206, (2005).

16. https://www.scribd.com/document/363272992/Des igning-a-Helical-Coil-Heat-Exchanger, accessed on March 2nd 2021.

17. Kulkarni H.B., Design and Development of Protype Cylindrical Parabolic Solar Collector for Water Heating Application, Int. J. Renewable Energi Development, Vol 5 No. 1, p: 49 55,(2016) http://dx.doi.org/10.14710/ijred.5.1.4955.

18. Ouannene M., Chaouachi B., Gabsi S., Design and Realization of A Parabolic Solar Cooker, International Symp. On the Heat and Mass Transfer in Sustainable Energy convective April $26^{\text {th }}$ to May $1^{\text {st }}$, Tunisia. (2009). 